\title{
Experimental study of electrode effects of resistance type electrodes for monitoring wood drying process above fibre saturation point
}

\author{
Valdek Tamme ${ }^{1^{*}}$, Peeter Muiste $^{1}$, Regino Kask ${ }^{1}$, Allar Padari ${ }^{1}$ and \\ Hannes Tamme ${ }^{2}$
}

Tamme, V., Muiste, P., Kask, R., Padari, A., Tamme, H. 2012. Experimental study of electrode effects of resistance type electrodes for monitoring wood drying process above fibre saturation point. - Forestry Studies | Metsanduslikud Uurimused 56, 42-55. ISSN 1406-9954.

\begin{abstract}
Due to practical need to improve the accuracy of measurement of wood electrical resistance via creating multivariate calibration models the study of electrode effects was carried out. The experiments were made in DC mode and five types of electrode effects were measured: electrical resistance of the galvanic contact between the measuring electrode and wood, corrosion of measuring electrodes in wet wood, polarization and depolarization of the double layer forming on the surface of the measuring electrodes, residual polarization voltage between measuring electrodes and effect of repeated use of measuring electrodes. For multi-channel measurement mode effect of neighbouring electrodes was measured. Behind each of these factors is a complex transfer mechanism of free and bounded charge carriers from wood to measuring electrodes. Among the factors, polarization and depolarization have an immediate effect (duration of the processes in seconds) while resistance of electrode/wood contact, corrosion of electrodes and residual polarization have a slow effect (duration of processes in hours). For pine sapwood, coefficients of the Stamm formula were found in moisture contents (MC) above the fibre saturation point. It was determined that wood polarization and depolarization indicators are dependent on wood moisture content as is the case with wood electrical resistance. Compared to wood electrical resistance, wood polarization proved approximately four times and depolarization approximately eight times less sensitive to moisture content variation.
\end{abstract}

Key words: wood drying, above FSP, corrosion, polarization.

Authors' addresses: ${ }^{1}$ Institute of Forestry and Rural Engineering, Estonian University of Life Sciences, Kreutzwaldi 5, Tartu 51014, Estonia; ${ }^{2}$ University of Tartu, Ülikooli 18, 50090 Tartu, Estonia; 'e-mail: valdek.tamme@emu.ee

\section{Introduction}

The electrical resistance method is widely used for monitoring wood drying since the method is economical and reliable (Tronstad et al., 2001, Onysko et al., 2008). But above fiber saturation point FSP (MC 30\%) the measurement is complicated as the measuring accuracy is insufficient and starts decreasing correspondingly to an increase in wood moisture content (Edwards, 1974;
Vermaas, 2002). The decrease in measuring accuracy can also be described quantitatively, by the 2S-value (Rozema, 2010). Insufficient measuring accuracy above FSP also reduces the accuracy of effective diffusion coefficient monitoring in the process of wood drying (Tamme et al., 2010, 2011). For precise determination of moisture content it is recommended to combine moisture meter measurements with the oven dry method for the measuring range above FSP 
(Brookhuis, 2009). This recommendation has been taken into account in this study.

The main empirical relationships and definitions of the resistance method have been given in studies (Stamm, 1927; Norberg, 1999).

The moisture content MC of wood, M, is generally defined as the ratio of the mass of water to the mass of dry wood:

$$
\mathrm{M}=\mathrm{m}_{\mathrm{water}} / \mathrm{m}_{\mathrm{dw}}
$$

where

$\mathrm{m}_{\text {water }}$ - mass of water

$\mathrm{m}_{\mathrm{dw}}-$ mass of dry wood.

$\mathrm{w}=100 \mathrm{M}$,

where

$\mathrm{w}$ - moisture content, $\mathrm{MC}$, in [\%].

The common relationship, originally proposed by Stamm (Stamm, 1927) expresses the effect of the wood MC on resistivity at a constant temperature:

$\log \rho=C+D \log M$,

where

$\rho$ - resistivity

$\mathrm{M}$ - moisture content, MC

$\mathrm{C}$ and D - constants at constant temperature.

This expression (3) was found to work satisfactorily within the typical range of the $\mathrm{MC}$, where electric moisture metes are used, i.e. $7-30 \%$.

In the case of electrical moisture meters, the $\mathrm{MC}$ is related to the resistance obtained for the given electrode configuration and for the given equivalent DC circuit.

For a given electrode configuration in the first approach:

where

$$
\mathrm{R}=\rho(\mathrm{L} / \mathrm{A})=\mathrm{K} \rho,
$$

$\mathrm{R}$ - resistance

$\mathrm{K}$ - cell constant, or measuring volume constant

L/A - cell constant for the particular electrode configuration

A - electrode/wood contact area, $\mathrm{mm}^{2}$

$\mathrm{L}$ - length between two electrodes.

Taking into account formulas (2), (3) and (4), ratio (3) may be replaced with an equivalent, yet a more convenient ratio for practical use:

$$
\log \mathrm{R}=\mathrm{C}_{1}+\mathrm{D} \log \mathrm{W},
$$

where

D - constant at a constant temperature

and the modified constant at a constant temperature

$$
\mathrm{C}_{1}=\mathrm{C}+\log \mathrm{K}-2 \mathrm{D}
$$

MC up to $40 \%$ of Douglas Fir can be calculated by the following equation (Straube et al., 2002):

$$
\log w=2.99-2.113(\log (\log R)) \text {, }
$$

where

$\mathrm{W}$ - moisture content in mass \%

$\mathrm{R}$ - resistance in Ohms $(\Omega)$.

In the measurement of wood DC resistance, the following factors are important:

a) electrical resistance of the galvanic contact between the measuring electrode and wood, b) corrosion of measuring electrodes in wet wood, c) polarization and depolarization of the double layer forming on the surface of the measuring electrodes (Metrohm Autolab B.V., Eco Chemie, http:// www.ecochemie.nl) and of the polar molecules of wood itself, d) residual polarization voltage between measuring electrodes, and lastly, e) effect of repeated application (repeated measurements) of measuring electrodes. Behind each of these factors is a complex transfer mechanism of free and bounded charge carriers from wood to measuring electrodes (James, 1975). Among the factors, polarization and depolarization have an immediate effect (duration of processes can be measured in seconds); whereas resistance of electrode/wood contact, corrosion of electrodes and residual polarization have a slow effect (duration of processes can be measured in hours).

These mechanisms can be examined in more detail with the help of certain alternate current (AC) equivalent circuits using electrical impedance spectrometry (EIS) (Zelinka, 2006, 2007; Metrohm Autolab B.V., Eco Chemie, http://www.ecochemie.nl)). The experience showed that the electrode effects involved in measuring wood electrical resistance should be observed in DC mode in order to avoid problems in using 
results obtained in AC mode for DC circuits.

Several experiments in DC mode were carried out during this research, the purpose of which was to assess five types of electrode effects both in terms of quantity and quality, mostly due to the practical need to minimise measurement errors in wood electrical resistance and also for creating multivariate calibration models.

\section{Material and Methods}

In studying electrode effects on a raw data file (set of unprocessed measurement data with numeric or analogous filters) of electrical resistance measurement (Fig. 4), a pine sapwood specimen with the dimensions of $100 \times 60 \times 60 \mathrm{~mm}$ (length $\times$ width $\times$ thickness) was used. It was dried in the climatic test chamber Feutron (Feutron, http://www.feutron.de) at room temperature $\left(20{ }^{\circ} \mathrm{C}, 96 \% \mathrm{RH}\right)$ in the stationary air for 90 hours and thereafter at $32{ }^{\circ} \mathrm{C}$ and $96 \%$ $\mathrm{RH}$ at the air velocity $0.4 \mathrm{~m} \mathrm{~s}^{-1}$ for another 244 hours. The specimen drying process lasted a total of 334 hours during which the wood MC was reduced from $146 \%$ to $36.4 \%$.

For slow processes like the resistance of electrode/wood contact and corrosion, the resistance meter Scanntronik Material Moisture Gigamodule with Scanntronik Thermofox data logger was used (Scanntronik Mugrauer Gmb, www. scanntronik.de). For measuring the voltage of the slow process of residual polarization, the profi-tester Meterman 38 XR was used (The Test Equipment Depot, http:// www.testequipmentdepot.com/meterman/dmm/38xr.htm/). In measuring slow processes, the minimum interval between two measurements was 1 hour. For measuring the fast process of polarization resistance, the resistance meter AlphaLab Inc. (http://www.trifield.com) was used within the measurement range of $0-20 \mathrm{M} \Omega$, with a measuring accuracy of $\pm 2 \%$. For saving measurement data in the data logger
Ahlborn (Type ALMEMO 2590-9) (Ahlborn, http://www.ahlborn.com/), an analogue output (with a range of $0-1 \mathrm{~V}$ ), which had a linear connection with the resistance measuring range of $0-20 \mathrm{M} \Omega$, was attached to the resistance meter AlphaLab. Readings of the analogue output and Alphalab display were related by the following formula: 10 (analogue output reading in volts $(\mathrm{V})=$ display reading in megaohms $(\mathrm{M} \Omega)$. The voltage of the analogue output could be measured at a speed of 10 measurements per second or 1 measurement per second by using the Ahlborn DC voltmeter ZA9000FS3. For measuring the voltage of another fast process, depolarization, the Meterman 38 XR profi-tester with an input resistance of 10 $\mathrm{M} \Omega$ was used, which enabled the measurement speed of 1 measurement per second. For the measurement during the experiments insulated pin electrodes were used (ram-in electrode M18, 60 mm, manufactured by Gann).

In the measurement of electrical resistance, polarization resistance, depolarization process and residual polarization, electrodes e1 and e2 were used at a distance of $\mathrm{L}=30 \mathrm{~mm}$ (measuring direction was across the grain) (see Fig. 2). In examining electrode/wood resistance $R_{c}$ and electrode corrosion, electrodes e1 and e2 as well as an extra pair of electrodes e 3 and e 4 were used at a distance of $\mathrm{L} / 2=15 \mathrm{~mm}$. The distance between the main measuring electrodes (e1, e2) and extra electrodes (e3, e4) was D $=40 \mathrm{~mm}$. Distance D was experimentally selected in order to avoid interaction between neighbouring electrodes, i.e. transmission of electrical potential by wet (143\% MC) wood. The difference between transmitted potentials (electrical voltage) was measured in dead neighbouring electrodes, which was below $1 / 30$ measuring voltage in the case of $\mathrm{D}=40 \mathrm{~mm}$.

The specimen was weighed with a scale manufactured by KERN (Model KERN EW B 620-M, resolution $0.01 \mathrm{~g}$ ) (Kern \& Sohn $\mathrm{GmbH}$, http://www.kern-sohn.com) at 24hour intervals on average; the oven dry 
Figure 1. Experimental setup. 1 - AlphaLab resistance meter,

2 - Scanntronic 8 channel resistance meter,

3 - box of reference resistances,

4 - switching box,

5 - climatic chamber Feutron.

Joonis 1. Eksperimendi aparatuur. 1 - AlphaLab takistusmõotja,

2 - Scanntronic 8 kanaliga takistusmõõtja,

3 - võrdlustakistite salv,

4 - lülituspaneel,

5 - kliimakamber Feutron.

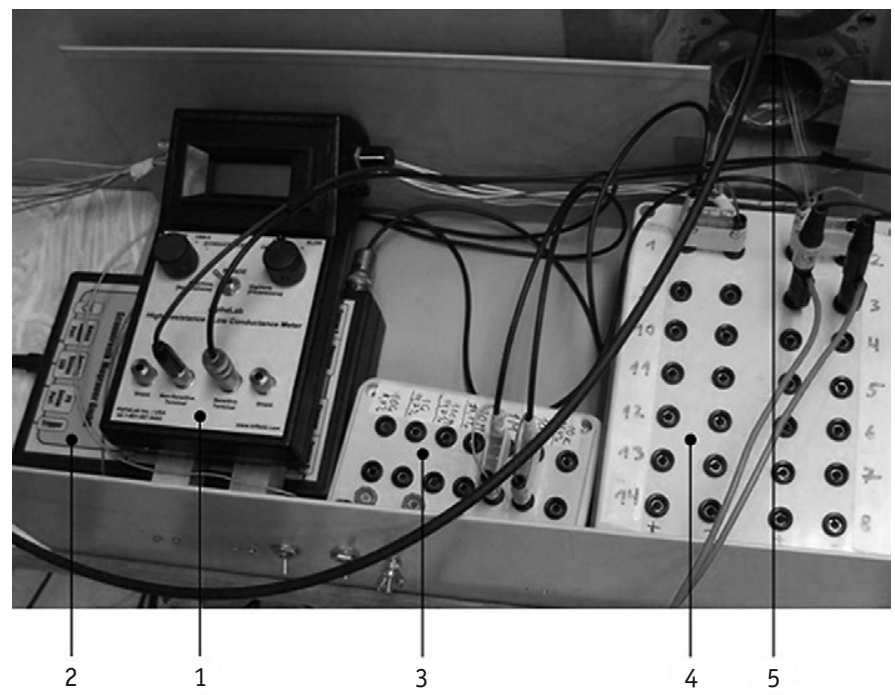

Figure 2. Arrangement of measuring electrodes on the examined specimen. All electrodes were placed at a depth of $20 \mathrm{~mm}$ from the surface of the specimen.

Joonis 2. Mõoteelektroodide paigutus uuritaval katsekehal. Kõik elektroodid olid paigutatud $20 \mathrm{~mm}$ sügavusele katsekeha pinnast.

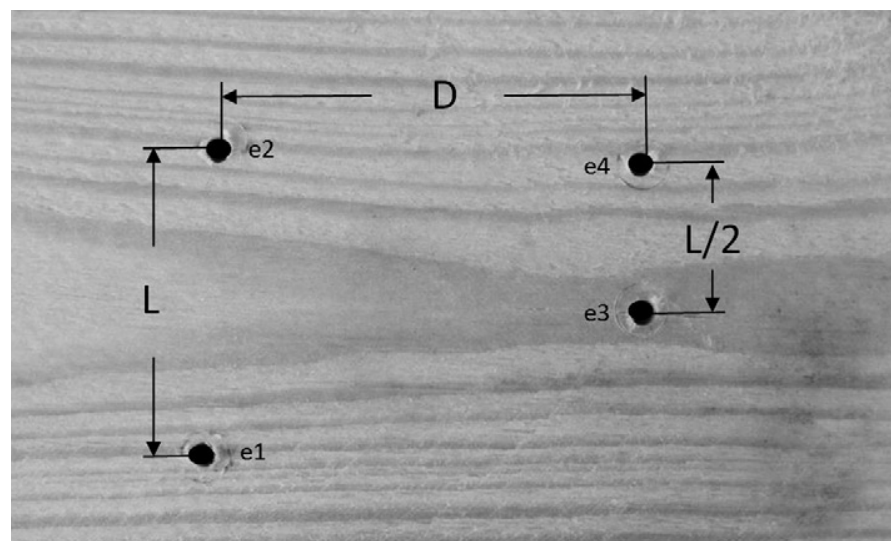

weight of the specimen was determined with the same scale.

Gann HT 85 T (Gann Mess- u. Regeltechnik GmbH, http://www.gann.de), NDT James Moisture Master (James Instruments Inc., http://www.ndtjames. com) and Brookhuis FMD-6 (Brookhuis, http://www.brookhuis.com) resistance type wood moisture meters were used in the experiments.

Unfortunately, the electrical resistance measurement raw file volume and internal data processing algorithm in the resistance meter Scanntronic Gigamodule and in the resistance type wood moisture meters used in the experiments remained hidden from the user. The experimental setup is depicted in Figure 1.

\section{Interaction registration methodology}

The methodological prerequisite for the registration of interactions in the research was the measurement of all examined interactions by DC measuring instruments with the same operating principle. That methodological restriction was necessary to work out a novel precise calibration method of a DC measuring instrument (but not an AC measuring instrument such as the EIS) of wood moisture:

a) resistance of electrode/wood contact on DC and b) electrode corrosion. 
According to studies (Norberg, 1999) and (James, 1993), $R_{c^{\prime}}$ resistance associated with the wood/electrode interface, and $R_{v}$, volume resistance, are series connected. By varying the distance $L$ between electrodes (see Fig. 2), a linear system of equation (7) may be proposed for the four-electrode measuring system:

$$
\begin{aligned}
& R_{1}=2 R_{c}+R_{v} \\
& R_{2}=2 R_{c}+0.5 R_{v},
\end{aligned}
$$

the solutions of which are:

$$
\text { and }
$$$$
R_{c}=R_{2}-0.5 R_{1} \text {, }
$$

$$
R_{v}=2\left(R_{1}-R_{2}\right),
$$

where

$R_{1}$ - resistance measured between electrodes (e1) and (e2) (see Fig. 2)

$R_{2}$ - resistance measured between electrodes (e3) and (e4)

$R_{c}$ - resistance of a single electrode/wood contact

$\mathrm{R}_{\mathrm{v}}$ - volume resistance.

The solution (7b) may also be the corrosion indicator. Analysis of solution behaviour is given in discussion.

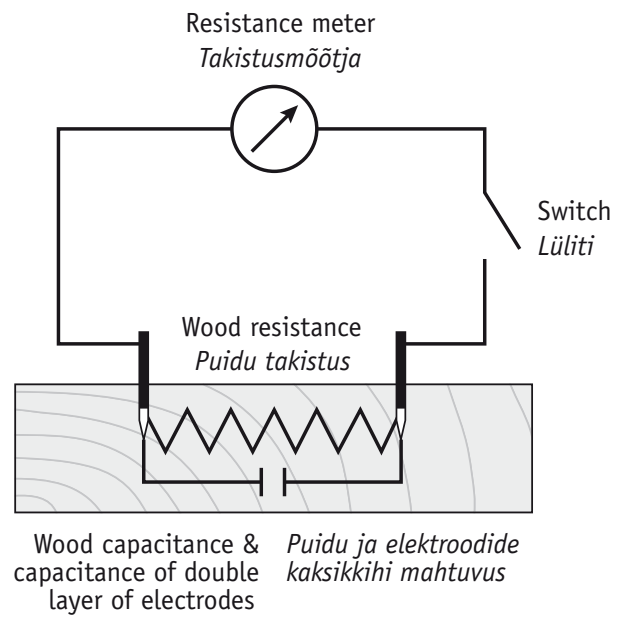

Figure 3. Simplified equivalent circuit for describing the processes of polarization and depolarization.

Joonis 3. Lihtsustatud ekvivalentskeem polarisatsiooni ja depolarisatsiooni protsesside kirjeldamiseks. c) polarization and depolarization. The polarization of the double surface layer of the electrodes and wood polarization are relaxation processes the simplified equivalent circuit of which is adapted (Onysko, 2008) and given in Figure 3. Polarization is expressed in the DC circuit by an increase in polarization resistance over time. As part of the experiment, the resistance meter AlphaLab allowed to measure it directly. Measuring polarization resistance enables the approximate assessment of the maximum measurement error in wood electrical resistance depending on wood moisture content. In depolarization process, voltage between the electrodes is the easiest to measure with the help of a DC voltmeter with high input resistance. This measuring method is also called a chronopotentiometric measurement (Metrohm Autolab B.V., Eco Chemie, http://www.ecochemie.nl). Measuring depolarization voltage allows a practical assessment of the time interval that is safe for beginning the next resistance measurement without risking the occurrence of a measurement error. Initial voltage relation $\mathrm{U}_{1} / \mathrm{U}_{0}$ (where $\mathrm{U}_{0}$ is the input voltage of the resistance meter and $U_{1}$ is the initial voltage of the depolarization process) and $T_{\max }$, the duration of the depolarization process, may also hypothetically be related to wood moisture content.

d) Residual polarization voltage between the measuring electrodes may hypothetically be caused by the difference between the corrosion potentials of the electrodes. Corrosion potential is usually measured with regard to a reference electrode used in electrochemistry (e.g. the $\mathrm{Ag} \cdot \mathrm{AgCl}$ reference electrode (Metrohm Autolab B.V., http://www.metrohm-autolab.com/Products/Echem/Accessories/accessories. html). Thus, residual polarization could be treated as the combined effect of the corrosion potential, measurement voltage of electrodes and the varied electrical mobility of positive and negative charge carriers. From a practical view point, residual polarization voltage would mean the occurrence 


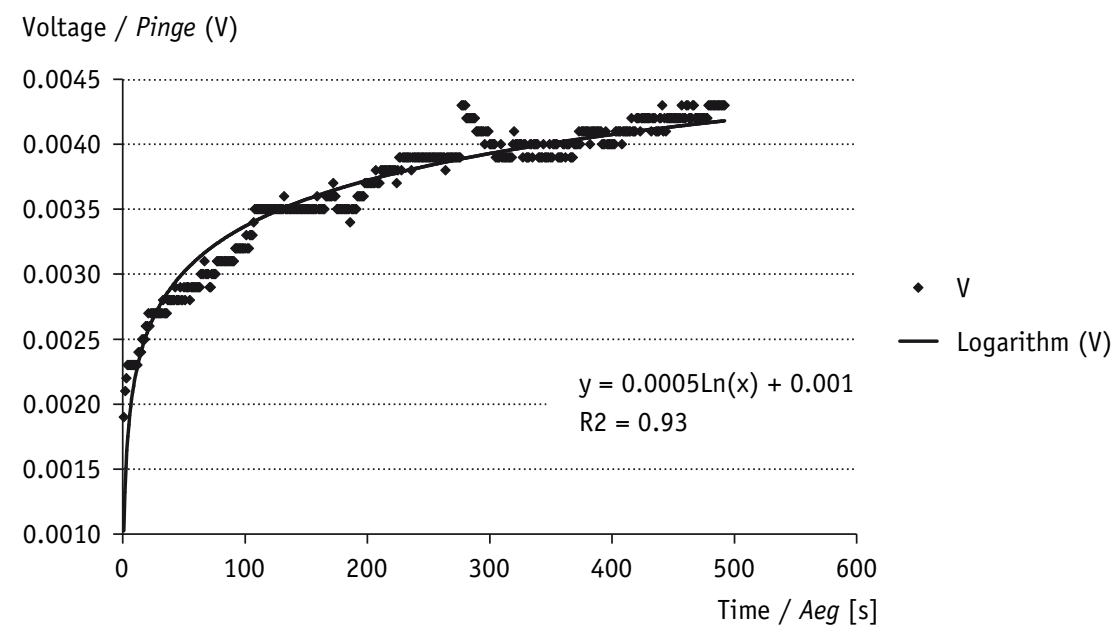

Figure 4. Example of polarization resistance measurement raw file at pine wood $\mathrm{MC} 146 \%$ and $20{ }^{\circ} \mathrm{C}$. Joonis 4. Näide polarisatsiooni takistuse mõõtmise toorfailist männi maltspuidus $146 \%$ NS ja $20^{\circ} \mathrm{C}$.

of a certain systematic error in measuring wood electrical resistance with a DC measuring device.

e) Effect of repeated application (repeated measurements) of pin electrodes.

The experiments made use of specimens made of five different tree species (Scots pine, Norway spruce, Grey alder, Birch and European aspen) with dimensions $(100 \times 60 \times 60 \mathrm{~mm})$ and resistance type wood moisture meters by three different manufacturers (Gann HT 85 T, FMD-6, and NDT James). Measuring electrodes (teflon insulated pins, $60 \mathrm{~mm}$ ) were tapped with a Gann hammer electrode (RAM- IN electrode M18) to a depth of $20 \mathrm{~mm}$ (1/3 of the thickness of the specimen). The number of specimens per each tree species was $n$ $=60$.

These types of measurements have a significant practical value in terms of moisture meter calibration, yet at the same time, while conducting measurements, several random factors need to be considered (for example, wood structure inhomogenity, moisture content gradients, etc.). The effect of the repeated use of electrodes is revealed in the moisture meters comparison test. It was assumed that electrode corrosion may be neglected when conducting short-term measurements of wood moisture content. In distributing moisture meters into accuracy classes by the $2 S$-value (Rozema, 2010), all other random factors must be kept at an equal a level as possible. The $2 S$-value indicates the range within which, with a 95\% certainty, the actual moisture content will fall if determined according to the oven dry method (Brookhuis, 2009).

In the test of moisture meters the electrical resistance of wood/electrode contact was measured indirectly via calibration and algorithm of processing the raw file of the electrical resistance measurement.

\section{Results and Discussion}

By comparing Figures 5 and 7, the figures seem to have a relatively similar shape. Based on this similarity, a hypothesis may be proposed that the resistance method owes its moisture sensitivity mainly to the resistance of the electrode/wood contact.

Figure 6 shows that during the drying process, wood volume resistance $R_{v}$ turns negative for a certain time period, and then back to positive, and maintains relatively stable (in a logarithmic scale). Reasonably 


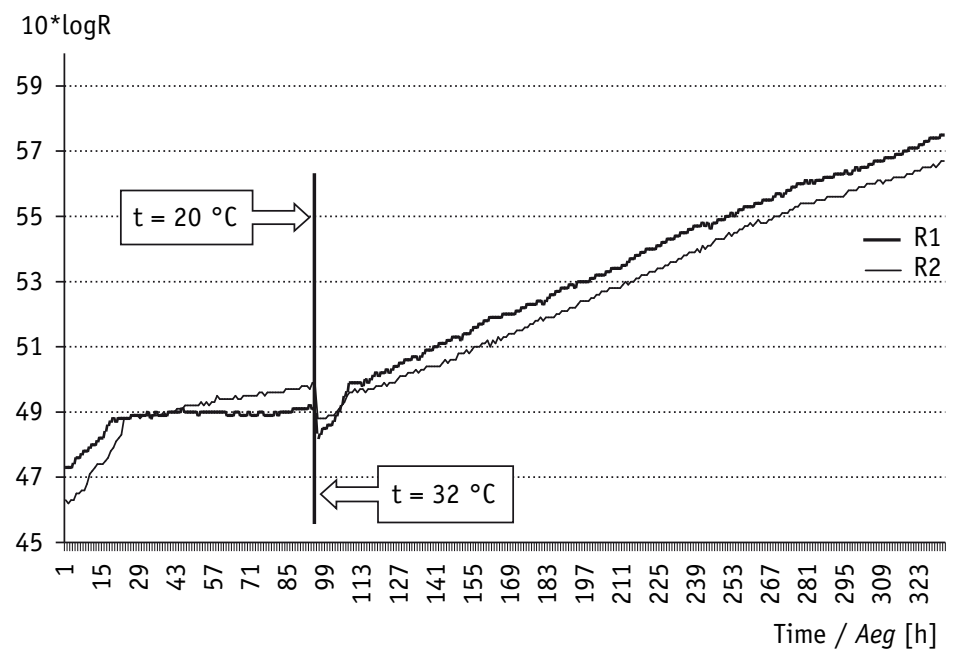

$10 * \log (\mathrm{Rv})$
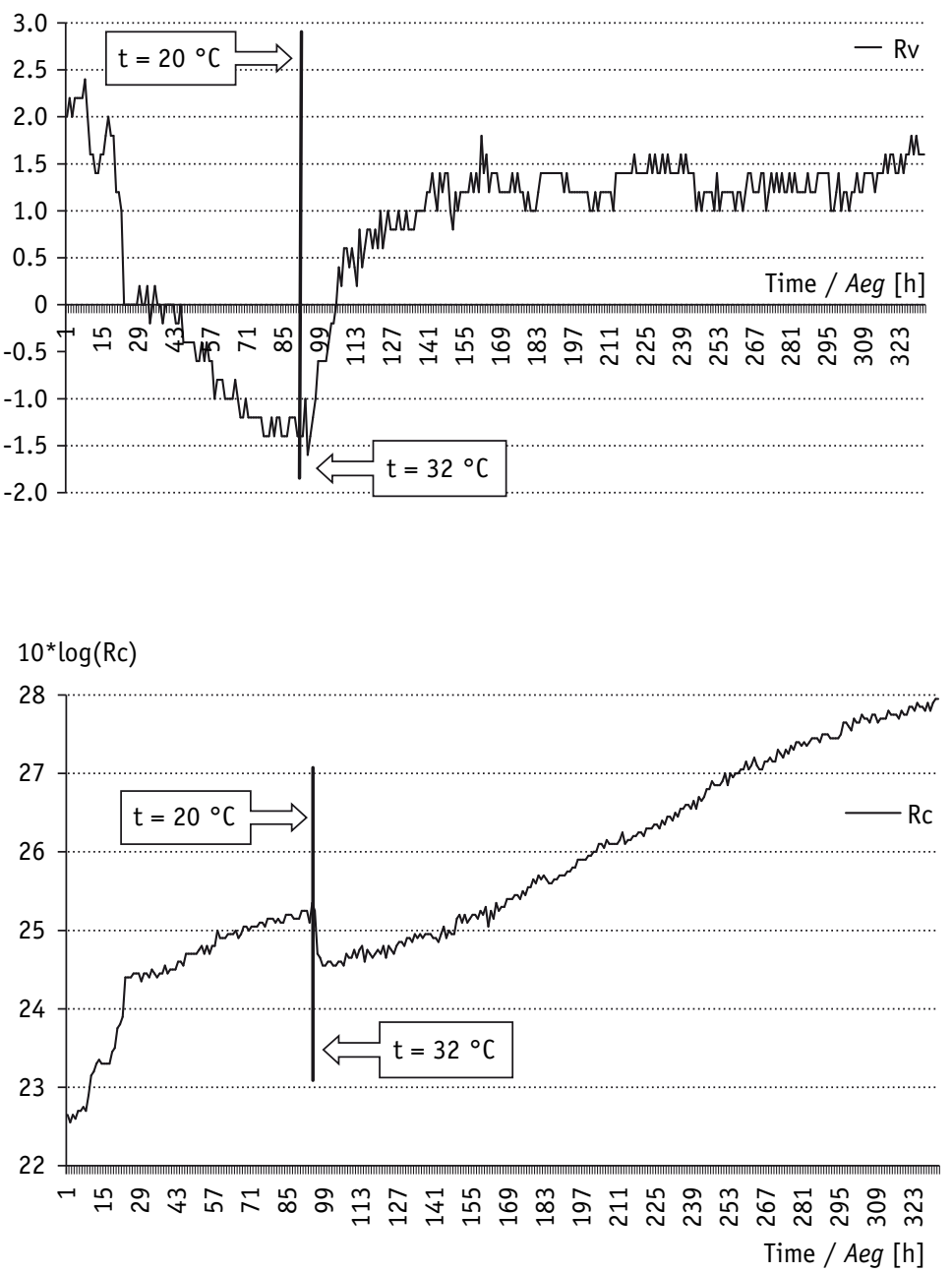

Figure 5. Monitoring of electrical resistance of pine sapwood specimen by using a four-electrode measuring system and Scanntronik Gigamodule resistance meter.

Joonis 5. Elektritakistuse monitooring männi maltspuidus, kasutades nelja elektroodiga mõõtesüsteemi ja Scanntronik Gigamodule takistusmõõtjat.

Figure 6 . Behaviour of volume resistance of wood.

Joonis 6. Puidu ruumtakistuse muutumine ajas.

Figure 7. Behaviour of electrode/wood contact resistance.

Joonis 7. Elektrood/puit kontakti takistuse muutumine ajas. 
(proceeding from general physical considerations), wood volume resistance cannot be effectively zero. This phenomenon may be explained by the following qualitative model of temperature dependent electrode corrosion affecting electrical resistance.

Step 1. For some random reason, accelerating corrosion occurs in one of the electrodes, or a pair of electrodes, and according to the measurement data of four-electrode measuring system it seems that wood volume resistance (in a logarithmic scale) turns negative.

Step 2. Logically, it may be assumed that accelerating corrosion in some electrodes cannot last for very long. Indeed, a more intense corrosion should result in an increase in the resistance of the electrode/ wood contact, and thus, current intensity through the more corroded pair of electrodes would decrease.

Step 3. Raising the temperature by $12{ }^{\circ} \mathrm{C}$ in the experiment intensified corrosion also in the rest of the electrodes and restored the equal speed of corrosion in all electrodes, thereby turning wood volume resistance back to positive.

When conducting measurements in a four-electrode measuring system (see Fig. 2) in DC mode, experiment results indicate a problem that volume resistance $R_{v}$ (values calculated according to formula (7b) may be somewhat underestimated. Therefore, volume resistance $\mathrm{R}_{\mathrm{v}}$ time graph (see Fig. 6) functions better as an indicator of corrosion. For a more accurate determination of volume resistance $R_{v^{\prime}}$ measurements of resistances $R_{1}$ and $R_{2}$ should be carried out in parallel both in DC mode and AC mode.
Figure 8 suggests that in wood moisture contents above FSP, the relative increment of polarization resistance may reach $120 \%$. If the initial resistance $R_{0}$ is viewed as approximately equal to wood resistance, the maximum wood resistance measurement error, upon not considering polarization resistance, may also reach $120 \%$. Figure 8 also shows that polarization resistance as well as the relative increment of polarization resistance, depending on time, is rather well-fitted with the logarithmic function. When measuring resistance in a logarithmic scale, polarization resistance can be quite easily subtracted from wood resistance by using instead of $R_{0}$ its calculated value $R_{0 \text { calc }}$ (regression curve value at time $0.1 \mathrm{sec}(\mathrm{t}=0.1 \mathrm{sec}))$. $R_{0 \text { calc }}$ values given in Table 1 have been calculated on the basis of regression curves adjusted for 60 -second intervals. For obtaining $\mathrm{R}_{\text {0calc }}$ more frequent measurements could be carried out during the first second of the polarization process as an alternative (e.g. 10-100 measurements per second) and then $\mathrm{R}_{0 \text { calc }}$ may be calculated on the basis of a linear function fitted to measured data.

Table 1 shows intervals of wood resistance plus polarization resistance values in comparison to data measured at the same time with Scanntronik Gigamodule, which have been recalculated from the logarithmic scale $10 \log R$ into resistance $R$, given in megaohms. According to Table 1, coordination between data on different resistance meters is satisfactory. Yet, it is unknown how the polarization resistance raw file in the Scanntronik Gigamodule resistance meter has been processed and whether and in which manner residual polarization volt-

Table 1. Quantities characteristic of the polarization process.

Tabel 1. Polarisatsiooni protsessi iseloomustavad suurused.

\begin{tabular}{lccccc}
\hline $\begin{array}{l}\text { Wood moisture } \\
\text { Puidu niiskus }(\%)\end{array}$ & $\begin{array}{c}\mathrm{R} 0,(\mathrm{M} \Omega), \\
\mathrm{t}=0 \mathrm{sec}\end{array}$ & $\begin{array}{c}\mathrm{R}_{\max }(\mathrm{M} \Omega), \\
\mathrm{t}=\sim 600 \mathrm{sec}\end{array}$ & $\begin{array}{c}\mathrm{R} 0_{\text {calc }}(\mathrm{M} \Omega), \\
\mathrm{t}=60 \mathrm{sec}\end{array}$ & $\begin{array}{c}\text { Gigamodule, } \\
\mathrm{R}(\mathrm{M} \Omega)\end{array}$ & $\begin{array}{c}(\mathrm{R}-\mathrm{R} 0) / \mathrm{R} 0) \\
100 \%\end{array}$ \\
\hline 146 & 0.017 & 0.043 & 0.011 & 0.054 & 126 \\
97.2 & 0.172 & 0.227 & 0.147 & 0.151 & 32.6 \\
36.4 & 0.59 & 0.73 & 0.52 & 0.56 & 23.7 \\
\hline
\end{tabular}




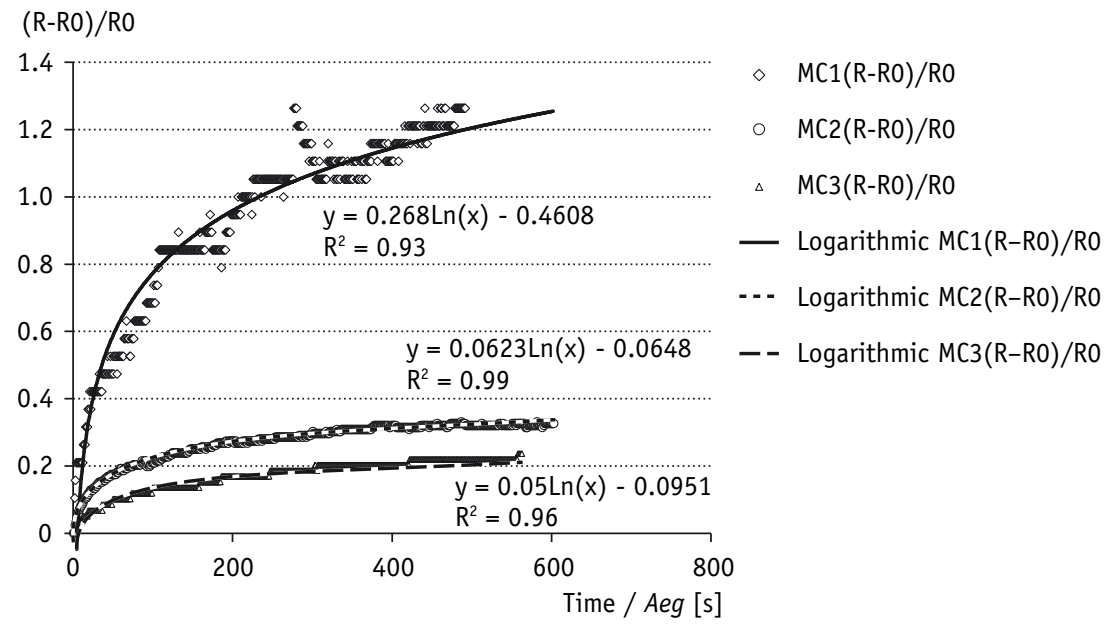

Figure 8. Relative increment of polarization resistance in pine sapwood at three different moisture contents: $M C 1=146 \% ; M C 2=97.2 \%$ and $M C 3=36.4 \%$

Joonis 8. Polarisatsiooni takistuse suhteline juurdekasv männi maltspuidus erinevatel niiskussisaldustel: NS1 $=146 \% ;$ NS2 $=97.2 \%$ ja NS3 $=36.4 \%$.

age as a possible source of a systematic error has been considered.

Figures 9 and 10 depicts that depolarization lasts longer in the case of wet wood, for ca 600 seconds. Measurements should continue only after the end of the depolarization process. Depolarization initial voltage relation $\mathrm{U}_{1} / \mathrm{U}_{0}$ and $\mathrm{T}_{\text {max }}$, the duration of the depolarization process also depend on wood moisture content according to Figure 9 and Table 2. Instead of using initial voltage $U_{1}$, more accurate calculations would be obtained by using its calculated value $U_{1 \text { calc }}$ (that is, the extrapolated value of the regression curve at $t=0.1 \mathrm{sec}$ ). Based on the above, it may be assumed that in the case of an equivalent circuit highly descriptive of the depolarization process, this process could also be used for measuring wood electrical resistance and wood moisture content.

Figure 11 shows that residual polarization voltage between measuring electrodes is relatively stable (average $-28.5 \mathrm{mV}$ ), but suggests a downward trend as wood moisture content decreases. For example, residual polarization voltage may lead to a sys- tematic measurement error when measuring wood resistance at input measuring voltage $3 \mathrm{~V}$ of the resistance meter, depending on measuring voltage polarity up to $\pm 1 \%$, and at measuring voltage $1 \mathrm{~V}$ up to $\pm 3 \%$, also in resistance measuring units, because the resistance scale has a linear connection with the input voltage.

Linear dependence (in a logarithmic scale) between moisture content and wood electrical resistance in the pine specimen is shown in Figure 12. Based on data given in Figure 12, it may be suggested that Stamm's well-known empirical relation (formulas 3 and 5 ) applies also in pine wood moisture contents above FSP (above MC 30\%). According to a common belief, this pattern is satisfactory only in the MC range of 7$30 \%$ (Norberg 1999). In the future, further research should determine the role played by the specific drying regime used in the experiment and tree species as well as the general (selected independently from the drying regime) empirical relation between wood electrical resistance and moisture content in the area above FSP in producing this quite a surprising result. 


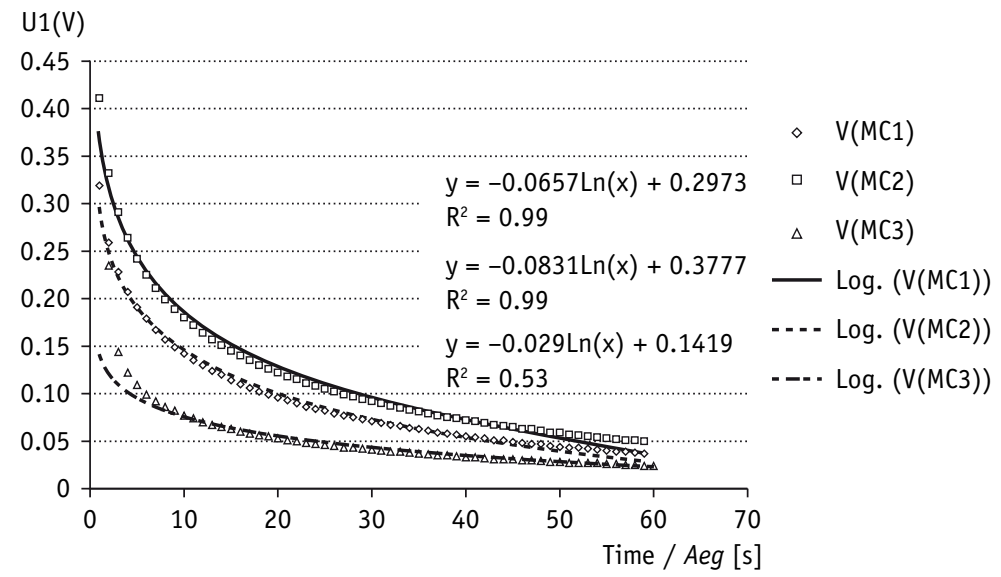

Figure 9. Changes in depolarization voltage of pine sapwood at three different moisture contents: MC1 $=146 \% ;$ MC2 $=97.2 \%$ and $M C 3=42.8 \%$

Joonis 9. Depolarisatsiooni pinge muutused männi maltspuidus kolmel erineval nïskusisaldusel: NS1 $=146 \% ;$ NS2 $=97.2 \%$ ja NS3 $=42.8 \%$.

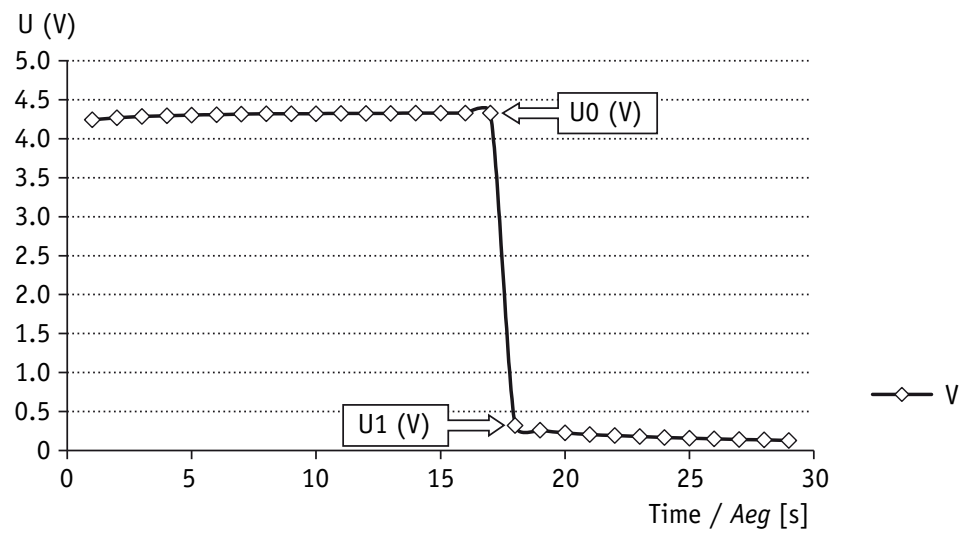

Figure 10. Depolarization initial voltage relation $U_{1} / U_{0}$ (initial voltages $U_{1}$ and $U_{0}$ ). Joonis 10. Depolarisatsiooni algpingete $U_{1} / U_{0}$ suhe (algpinged $U_{1}$ ja $U_{0}$ ).

Table 2. Quantities characteristic of the depolarization process.

Tabel 2. Depolarisatsiooni protsessi iseloomustavad suurused.

\begin{tabular}{lcccc}
\hline $\begin{array}{l}\text { Wood moisture } \\
\text { Puidu niiskus, }(\%)\end{array}$ & $\left(\mathrm{U}_{1} / \mathrm{U}_{0}\right) 100 \%$ & $\begin{array}{c}\mathrm{T}_{\max }\left(\mathrm{U}_{1}=0\right), \\
\mathrm{sec}\end{array}$ & $\begin{array}{c}\left(\mathrm{U}_{1, \text { calc }} / \mathrm{U}_{0}\right) 100 \%, \\
\mathrm{t}=60 \mathrm{sec}\end{array}$ & $\begin{array}{c}\left(\mathrm{U}_{1} / \mathrm{U}_{0}\right) \mathrm{T}_{\max }, \\
\mathrm{sec}\end{array}$ \\
\hline 146 & 7.4 & 600 & 10.37 & 44.4 \\
97.2 & 4.5 & 488 & 6.66 & 21.96 \\
42.8 & 2.5 & 335 & 3.33 & 8.38 \\
\hline
\end{tabular}




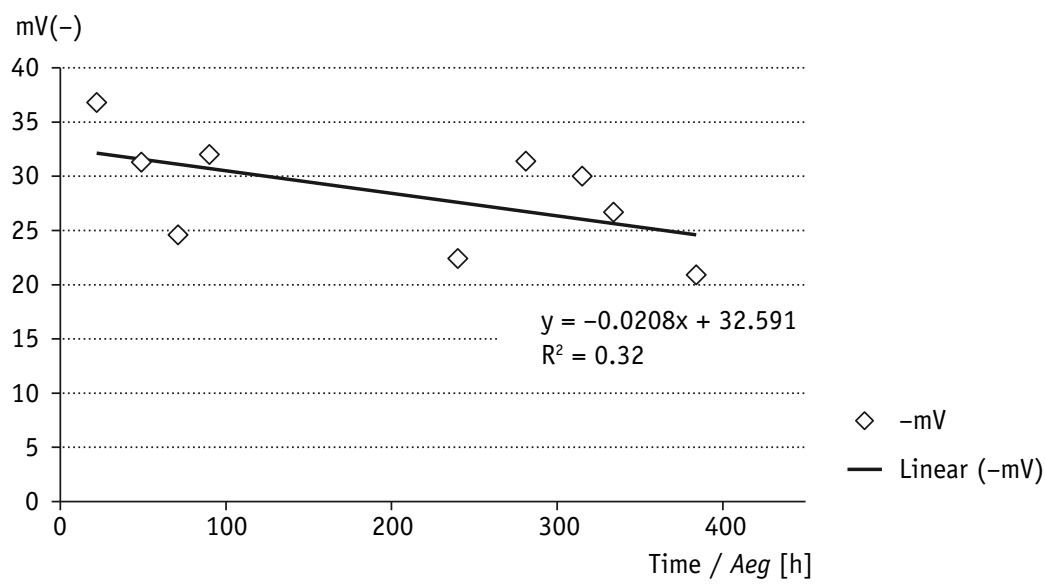

Figure 11. Changes (variation) in residual polarization voltage measured in the specimen during drying. The moisture content of the specimen varied respectively from $146 \%$ to $36.4 \%$.

Joonis 11. Männi maltspuidust katsekeha kuivatamise käigus mõõdetud jääkpolarisatsiooni pinged. Katsekeha niiskussisaldus (NS) muutus alates $146 \%$ kuni $36.4 \%$.

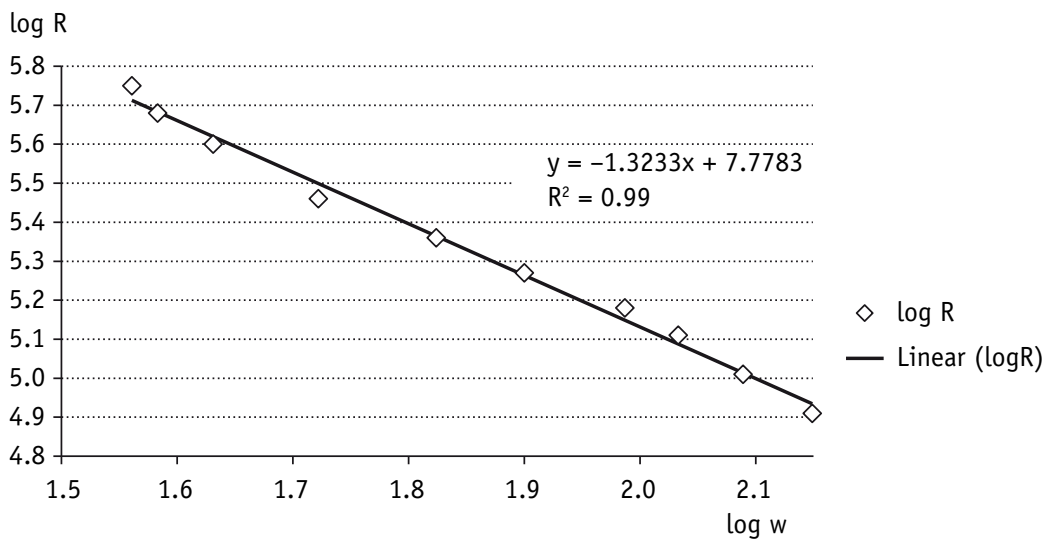

Figure 12. Empirical relation between pine sapwood moisture content and electrical resistance at $32{ }^{\circ} \mathrm{C}$. The moisture content of the specimen decreased from $141 \%$ to $36.4 \%$.

Joonis 12. Empiiriline seos männi maltspuidu niiskussisalduse ja elektritakistuse vahel temperatuuril $32{ }^{\circ} \mathrm{C}$. Katsekeha niiskussisaldus vähenes $141 \%$ kuni $36.4 \%$.

For the specific drying regime and type of pin electrodes used in the experiments, the average electrode/wood contact area of both electrodes was $\mathrm{A}=94.8 \mathrm{~mm}^{2}$ and distance between electrodes was $\mathrm{L}=30 \mathrm{~mm}$. Based on this data, cell constant $K$, and based on Figure 1, also constants in formula (5) could be calculated: $C_{1}=7.7783$ and $D=$ -1.3233 . For the Stamm formula (3), respec- tive values of the constants are the following: $C=5.63$ and $D=-1.3233$. Formula (6) was applied for calculating the value of constant C. All constants have been determined for pine sapwood and the constant temperature of $32{ }^{\circ} \mathrm{C}$.

By comparing the figures given in Tables 1 and 2, the estimated average moisture sensitivity of different measuring processes 
Table 3. $2 S$ values of MC readings (acc. to Rozema, 2010) of wet and dry wood (above FSP and below FSP) measured with different moisture meters. Number of specimens $n=60 \times 5$.

Tabel 3. 2S väärtused erinevate niiskusmõõtjatega saadud NS lugemitele (vastavalt Rozema, 2010 artiklile).

\begin{tabular}{|c|c|c|c|c|c|}
\hline $\begin{array}{l}\text { Type of Mois- } \\
\text { ture meter } \\
\text { Nïiskusmõõtja } \\
\text { tüüp }\end{array}$ & $\begin{array}{l}\text { Scots pine heart- } \\
\text { wood, average } \\
\text { actual MC wet } \\
34.2 \% \text { | dry } 27 \% \\
\text { Männi lülipuit } \\
\text { keskmine tegelik } \\
\text { niiskussisaldus } \\
\text { märg | kuiv } \\
\end{array}$ & $\begin{array}{l}\text { Norway spruce } \\
\text { heartwood, aver- } \\
\text { age actual MC wet } \\
31.3 \% \mid \text { dry } 27.1 \% \\
\text { Kuuse lülipuit } \\
\text { kesmine tegelik } \\
\text { niiskussisaldus } \\
\text { märg| kuiv }\end{array}$ & $\begin{array}{l}\text { Grey alder, av- } \\
\text { erage actual MC } \\
\text { wet } 105.7 \% \mid \\
\text { dry } 31.6 \% \\
\text { Hall lepp } \\
\text { kesmine tegelik } \\
\text { niiskussisaldus } \\
\text { märg | kuiv }\end{array}$ & $\begin{array}{l}\text { Birch, average } \\
\text { actual MC wet } \\
85.2 \% \mid \text { dry } \\
30.3 \% \\
\text { Kask keskmine } \\
\text { tegelik nïskus- } \\
\text { sisaldus } \\
\text { märg| kuiv } \\
\end{array}$ & $\begin{array}{l}\text { European aspen, } \\
\text { average actual } \\
\text { MC wet } 107 \% \mid \\
\text { dry } 29.9 \% \\
\text { Haab keskmine } \\
\text { tegelik niiskus- } \\
\text { sisaldus } \\
\text { märg | kuiv }\end{array}$ \\
\hline $\begin{array}{l}\text { GANN HT } 85 \mathrm{~T} \\
2 \mathrm{~S} \text {-value }\end{array}$ & 3.8 | 2.4 & $2.4 \mid 1.0$ & $2.6 \mid 1.6$ & $4.2 \mid 2.8$ & $2.6 \mid 3.5$ \\
\hline $\begin{array}{l}\text { FMD-6 } \\
\text { 2S-value }\end{array}$ & $3.0 \mid 2.2$ & $1.8 \mid 1.0$ & $7.4 \mid 1.4$ & $2.4 \mid 2.2$ & $1.8 \mid 3.5$ \\
\hline $\begin{array}{l}\text { NDT James, } \\
\text { 2S-value }\end{array}$ & $2.2 \mid 2.6$ & $3.2 \mid 2.6$ & $2.2 \mid 2.8$ & $2.2 \mid 2.8$ & $2.0 \mid 2.7$ \\
\hline
\end{tabular}

Bold numbers - Not measurable, if $2 S$-value $>3.5 \%$.(acc. to Rozema, 2010).

MC - moisture content (\%), determined by indirect (electrical resistance) and direct (oven-dry) methods.

Paksud numbrid - Mitte mõõdetav, kui 2S-väärtus > 3.5\% (vastavalt Rozema, 2010 artiklile).

NS - niiskusisalduse (\%), mis on määratud kaudsel (elektritakistuse) ja otsesel (kuivkaalumise) meetodil.

may be determined. A two-fold increase in wood moisture content $(97.2 \%$ up to $146 \%)$ brought about a corresponding increase in depolarization initial voltage relation $\left(\left(\mathrm{U}_{1} / \mathrm{U}_{0}\right) 100 \%\right)$, a four-fold increase in the relative increment of polarization resistance ((R-R0)/R0)100\%), and an eight-fold increase in the measured electrical resistance R0. Thus, the measurement of electrical resistance seems to involve the highest moisture sensitivity, followed by the measurement of the relative increment of polarization resistance, and lastly, the measurement of depolarization initial voltage relation. In the practical use of the methods for measuring wood moisture content, the moisture sensitivity of a method is not the only selection criterion. It is also essential to minimize the variance of the measurement data recorded. A more detailed research of moisture sensitivity and variance would require more measurement data.

A comparison of the values of quantity $2 S$ by tree species in Table 3 indicates a trend in all tree species that $2 S$ values decrease in accordance with a decrease in wood moisture content. Aspen wood is the only exception with its increasing $2 S$ val- ues. It might be that drying results in larger moisture gradients in aspen wood compared to other tree species. This phenomenon with aspen wood requires in-depth future research.

The analysis by DC measuring mode enables adding the following variables in the multivariate statistical model for calibration: 1) gravimetric wood MC, 2) wood/ electrode contact resistance, 3) volumetric resistance of wood, 4) relative increment of polarization resistance, 5) time constant of the polarization process at given wood moisture levels, 6) depolarization initial voltage relation, 7) time constant of the depolarization process at given wood moisture levels, 8) multiplication of the depolarization initial voltage relation and total process time, 9) residual polarization voltage (or charge). All variables are defined on the assumption that the temperature is constant.

\section{Conclusions}

Knowledge of electrode effects enables improved consideration and prevention of random factors reducing calibration quality 
of resistance type wood moisture meters in wood moisture contents above FSP.

To improve the accuracy of measurement of wood electrical resistance the study presented a novel approach. The additional variables were generated for the multivariate statistical model for calibration. Application of these variables presumably improves the $R^{2}$ value of the model and minimises its standard error compared to the simple calibration model with one independent variable $(\mathrm{y} \sim \mathrm{x})$.

The outcomes of the study were approximate error estimates and suggestions for five different types of electrode effects, which should be considered when organising the calibration process of resistance type wood moisture meters in the range above FSP.

Acknowledgements. The work was supported by the Environmental Investment Centre of Estonia (Grant No. 906).

\section{References}

Ahlorn. [WWW document]. - URL http:/ / www.ahlborn.com . [Accessed August 20, 2013].

AlphaLab Inc. [WWW document]. - URL http:/ / www. trifield.com . [Accessed August 20, 2013].

Brookhuis Micro-Electronics BV. 2009. Moisture measuring manual Version 1.4. 27 pp.

Brookhuis. [WWW document]. - URL http://www. brookhuis.com . [Accessed August 20, 2013].

Edwards, N.C. 1974. Procedure for the determination of species correction data for electrical resistance type moisture metes. - CSIRO Div. For. Prod. (Unpublished divisional report). $10 \mathrm{pp}$.

Feutron. [WWW document]. - URL http://www. feutron.de . [.Accessed August 20, 2013].

Gann Mess- u. Regeltechnik GmbH. [WWW document]. - URL http://www.gann.de . [Accessed August 20, 2013].

James Instruments Inc. [WWW document]. - URL http://www.ndtjames.com . [Accessed August 20, 2013].

James, W.L. 1975. Dielectric properties of wood and hard-board: Variation with temperature, frequency, moisture content, and grain orientation. - Research Paper FPL 245. USDA Forest Prod. Lab. Madison, WI.

James, W.L. 1993. Fundamentals of hand held moisture metes: An outline. - Proceedings. ASTM Hand
Held Moisture Meter Workshop, Madison, WJ, Forest Product Society, May 5, 1993, 13-16.

Kern \& Sohn GmbH. [WWW document]. - URL http://www.kern-sohn.com . [Accessed August 20, 2013].

Metrohm Autolab B.V. [WWW document]. - URL http:/ / www.metrohm-autolab.com/Products/ Echem/Accessories/ . [Accessed August 20, 2013].

Metrohm Autolab B.V., Eco Chemie. [WWW document]. - URL http://www.ecochemie.nl . [Accessed August 20, 2013].

Norberg, P. 1999. Monitoring wood moisture content using the WETCORR method. - Holz als Roh- und Werkstoff, V, 57, 448-453.

Onysko, D.M., Schumacher, C., Garrahan, P. 2008. Field Measurement of Moisture in Building Materials and Assembles: Pitfalls and Error Assessment. - Best 1 Conference - Building Enclosure Science \& Technology, June 10-12, 2008, Minneapolis.

Rozema, P. 2010. Do's and don'ts in respect to moisture measurement. - The Final Conference of COST Action E 53 ,The Future of Quality Control for Wood \& Wood Products", May $4-7^{\text {th }}, 2010$, Edinburgh.

Scanntronik Mugrauer Gmb. [WWW document]. - URL http://www.scanntronik.de . [Accessed August 20, 2013].

Stamm, A.J. 1927.The electrical resistance of wood as a measure of it's moisture content. - Industrial and Engineering Chemistry, V, 19(9), 1021-1025.

Straube, J., Onysko, D., Schumacher, C. 2002. Methodology and Design of Field Experiments for Monitoring the Hygrothermal Perfomance of Wood Frame Enclosures. - Journal of Thermal Envelope and Building Science, V, 26, No. 2.

Tamme, V., Muiste, P., Mitt, R., Tamme, H. 2011. Determination of Effective Diffusion Coefficient and Mechanical Stress of Pine Wood During Convective Drying. - Baltic Forestry, V, 17, 110-118.

Tamme, V., Muiste, P., Polyachenko, R., Tamme, H. 2010. Determination of Dynamics of Moisture content, Temperature and Mechanical Stress of Pine Wood During Convective Drying. - Proceedings of the $11^{\text {th }}$ International IUFRO Wood Drying Conference, Skellefteå, Sweden, 2010, 147-154.

The Test Equipment Depot. [WWW document]. - URL http://w ww.testequipmentdepot.com/meterman/dmm/38xr.htm/ . [Accessed August 20, 2013].

Tronstad, S., Sandland, K., Toverød, M.H. 2001. Drying quality of softwood based on 140 industrial tests in Norwegian sawmills and actions to improve the quality. - Paper on $3^{\text {rd }}$ Workshop on softwood drying to specific end-uses, COST Action E15, Advances in the drying of wood (1999-2003). VTT Building and Transport, June 11-13, 2001, Espoo, Finland. 13 pp. 
Vermaas, H.F. 2002. State of the Art and Latest Technological Advances in the Drying of Fast-grown Eucalyptus. $-4^{\text {th }}$ COST E15 Workshop "Methods for Improving Drying Quality of Wood“, May 30-31, 2002, Santiago de Compostela, Spain. 17 pp.

Zelinka, S.L., Rammer D.L. 2006. Electrochemical method for measuring corrosion of metals in wood. - WCTE 2006 - $9^{\text {th }}$ World Conference on Timber Engineering. Portland OR. 9pp.

Zelinka, S.L., Stone, D.S., Rammer, D.L. 2007. Equivalent circuit modeling of wood at $12 \%$ moisture content. - Wood and Fiber Science, V, 39(4), 556-565.

\title{
Elektroodefektide uurimine puidu kuivatamisel niiskus- sisaldustel üle kiu küllastuspunkti
}

\author{
Valdek Tamme, Peeter Muiste, Regino Kask, Allar Padari ja Hannes Tamme
}

\section{Kokkuvõte}

Puidu kuivatuse monitooringul on elektriline takistusmeetod laialdaselt kasutusel. Kuid probleeme tekitab puidu niiskussisalduse (NS) määramine üle kiu küllastuspunkti (s.o. NS vahemikus 30\% kuni 170\% puidu kuivkaalu suhtes), kus on põhilisteks probleemideks ebapiisav mõõtetäpsus ja tulemuste vähene korratavus, mille tõttu pole seni onnestunud saada sellele meetodile mainitud piirkonnas rahuldavat kalibreerimiskõverat. Selle artikli eesmärgiks oli eksperimentaalselt uurida puidu ja mõõteelektroodide vastastikust toimet. Elektroodefekte uuriti puidu kuivatamisel üle kiu küllastuspunkti, madalatel temperatuuridel $\left(20{ }^{\circ} \mathrm{C}\right.$ ja $\left.30{ }^{\circ} \mathrm{C}\right)$ ja leebetel kuivatusrežiimidel (98\% RH ja 96\% RH õhu suhtelisel niiskussisaldusel). Katsetes kasutati kahe erineva tootja elektrilise takistuse mõõtjat ja kolme erineva tootja takistus-tüüpi puidu niiskuse mõõtjat. Ühesugustes tingimustes $\left(32{ }^{\circ} \mathrm{C}\right.$ ja $96 \%$ RH ja puidu NS piirkonnas üle kiu küllastuspunkti), katsekehi kuivatati ja teatud ajavahemike järel mõõdeti niiskussisaldusi viiest erinevast puiduliigist (Pinus sylvestris, Picea abies, Alnus glutinosa, Betula pendula, Populus tremula) valmistatud katsekehadel mõõtmetega 100×60×60 mm (pikkus, laius, paksus). Kokku oli eksperimendis 500 katsekeha. Statistiliselt analüüsiti elektroodide korduva paigaldamise mõju mõõtmistulemuste korratavusele. Männi maltspuidus (niiskussisalduste piirkonnas üle kiu küllastuspunkti) uuriti lisaks ka mõõteelektroodide korrosiooni, polarisatsiooni ja depolarisatsiooni protsesside mõju elektritakistuse mõõtetulemustele. Selle uurimuse peamiste tulemustena võib esile tõsta järgmisi tulemusi: 1) Määrati eksperimentaalselt Stamm'i valemi koefitsiendid uuritava (üle kiu küllastuspunkti) puidu niiskuste vahemiku jaoks. 2) Stamm'i valem annab funktsionaalse sõltuvuse puidu niiskussisalduse ja puidu elektritakistuse vahel. Lisaks sellele sõltuvusele (nn. Stamm'i protsess), leiti veel kaks protsessi (polarisatsiooni ja depolarisatsiooni protsessid), mis samuti osutusid puidu niiskusest sõltuvaiks. Kõigi kolme protsessi jaoks leiti ligikaudsed niiskustundlikkuste suhtarvud. 3) Leiti lihtne protseduur puit/elektrood kontakti takistuse ja puidu ruumtakistuse eraldamiseks (e. separeerimiseks). 4) Katsetulemuste alusel valiti välja olulisemad füüsikalised parameetrid, mis võivad edaspidi leida rakendust puidu niiskusmõõtjate kalibreerimisel mitme muutujaga statistilistes mudelites. Selles uurimuse tulemuste interpreteerimise käigus püstitati ka kaks hüpoteesi üks jääkpolarisatsiooni nähtuse selgituseks, ja teine Stamm'i protsessi niiskustundlikkuse selgituseks. Selle uurimuse tulemusi on võimalik kasutada takistus-tüüpi puidu niiskusmõõtjate kalibreerimise protseduuri organiseerimisel puidu niiskussisaldustel üle kiu küllastuspunkti. 